\title{
Biology, Pathophysiological Role, and Clinical Implications of Exosomes: A Critical Appraisal
}

\author{
Arif Tasleem Jan ${ }^{1, *,+}$, Safikur Rahman ${ }^{2,+} \oplus$, Shahanavaj Khan ${ }^{3}$, Sheikh Abdullah Tasduq ${ }^{4}$ and \\ Inho Choi ${ }^{2, *}$ \\ 1 School of Biosciences and Biotechnology, Baba Ghulam Shah Badshah University, Rajouri 185236, India \\ 2 Department of Medical Biotechnology, Yeungnam University, Gyeongsan 38541, Korea; \\ shafique2@gmail.com \\ 3 Department of Bioscience, Shri Ram Group of College (SRGC), Muzaffarnagar 251001, India; \\ khan.shahanavaj@gmail.com \\ 4 CSIR-Indian Institute of Integrative Medicine, Canal Road, Jammu 180001, India; stabdullah@iiim.ac.in \\ * Correspondence: atasleem@bgsbu.ac.in (A.T.J.); inhochoi@ynu.ac.kr (I.C.); Tel.: +82-53-8103024 (I.C.) \\ + These authors contributed equally to this work.
}

Received: 28 December 2018; Accepted: 28 January 2019; Published: 29 January 2019

\begin{abstract}
Exosomes are membrane-enclosed entities of endocytic origin, which are generated during the fusion of multivesicular bodies (MVBs) and plasma membranes. Exosomes are released into the extracellular milieu or body fluids; this process was reported for mesenchymal, epithelial, endothelial, and different immune cells (B-cells and dendritic cells), and was reported to be correlated with normal physiological processes. The compositions and abundances of exosomes depend on their tissue origins and cell types. Exosomes range in size between 30 and $100 \mathrm{~nm}$, and shuttle nucleic acids (DNA, messenger RNAs (mRNAs), microRNAs), proteins, and lipids between donor and target cells. Pathogenic microorganisms also secrete exosomes that modulate the host immune system and influence the fate of infections. Such immune-modulatory effect of exosomes can serve as a diagnostic biomarker of disease. On the other hand, the antigen-presenting and immune-stimulatory properties of exosomes enable them to trigger anti-tumor responses, and exosome release from cancerous cells suggests they contribute to the recruitment and reconstitution of components of tumor microenvironments. Furthermore, their modulation of physiological and pathological processes suggests they contribute to the developmental program, infections, and human diseases. Despite significant advances, our understanding of exosomes is far from complete, particularly regarding our understanding of the molecular mechanisms that subserve exosome formation, cargo packaging, and exosome release in different cellular backgrounds. The present study presents diverse biological aspects of exosomes, and highlights their diagnostic and therapeutic potentials.
\end{abstract}

Keywords: exosomes; extracellular transport; diseases; secretory vesicles; stem cells

\section{Introduction}

The existence of exosomes as extracellular vesicles (EVs) was first reported by Harding et al. and Johnstone et al. [1,2]. Unlike microvesicles (MVs; 100-1000 nm) and apoptotic bodies (50-500 nm), exosomes are membrane-enclosed vesicles of endocytic origin that range in size from 30 to $100 \mathrm{~nm}$. Their secretions to the extracellular milieu and body fluid compartments (bronchoalveolar lavage, synovial fluid, bile, serum, milk, and urine) were reported for a variety of cells (mesenchymal cells, fibroblasts, epithelial cells, platelets, antigen-presenting cells, and tumor cells) [3-6]. In addition to simple budding at plasma membrane surface (ectosomes, micro-particles, microvesicles), exosomes are produced in a well-organized two-step process that involves membrane invagination and vesicle 
budding. Exosomes are loaded with different molecules, such as nucleic acids, cytokines, bioactive compounds, and enzymes, and surface-encoded proteins present as receptors on exosomes act on neighboring cells either by inducing signaling pathways or affecting their cellular phenotypes by transferring new genetic material and receptors [7-11]. Furthermore, their secretions to the extracellular milieu influence host immune systems $[3,12,13]$.

Exosome discovery is bearing fruit, as evidenced by an enormous increase in the number of studies on exosome biology and the establishment of scientific societies like the American Society for Exosomes and Microvesicles (ASEM) and the International Society for Extracellular Vesicles (ISEV). This explosive growth of exosome biology even resulted in a journal Journal of Extracellular Vesicles, and the establishment of the Exocarta and Vesiclepedia databases, which are dedicated to extracellular vesicles. The extracellular RNA (exRNA) research portal is the result of an initiative by the Extracellular RNA Communication Consortium (ERCC) that provides a catalog of extracellular RNAs (exosomes are potential RNA carriers), and reports on the mechanisms of exRNA generation, secretion, transport, therapeutic uses, and their uses as biomarkers of disease. In addition to their importance as signaling molecules for intercellular communication and regulation, exosomes offer potential means of ameliorating pathogenic immune responses, diagnosing different diseases, and delivering therapeutics. Here, we summarize essential findings of exosome biology, and provide an up-to-date account of their diverse physiological and pathological functions.

\section{Isolation and Characterization}

Exosomes made their entrance into the scientific world three decades ago. Late endosomes were considered as pre-degradative compartments, and the vesicular structures secreted by late lysosomes were considered as the membranous entities of dying cells. As technical problems in the isolation methods hamper their separation from other vesicle types, no consensus was reached on their isolation methods. The existence of exosomes became apparent when reticulocyte culture supernatant was purified by ultracentrifugation, and they were only recognized as functional entities by electron microscopy [14]. Ultracentrifugation at $\geq 100,000 \times g$ is routinely used to obtain exosomes from culture supernatants. Although the technique excludes contamination by dead cell debris, it results in mixed fractions of exosomes, protein aggregates, and vesicular structures. Other isolation methods include serial filtration [15], immunoaffinity purification against surface proteins [16], and commercially available kits, which allow rapid, straight forward isolation. Confirmation that isolated vesicles are exosomes is achieved by laser scatter tracking, electron microscopy, and other techniques such as mass spectrometry [17-20].

Observations of exosomes by whole-mount electron microscopy revealed them to be "saucer-like" or "deflated-football" shaped, believed to be due to vesicle collapse during sample preparation [21]. Although Harding reported in 1983 that exosomes are generated as multivesicular entities (MVEs) [2], their vesicular characteristics were established by Pan and Johnstone in a study of the transition of sheep reticulocytes [22]. The enrichment of Rab GTPases (Rab4 and Rab5), which act as membrane traffic regulators in exosomes, was first reported by Vidal and Stahl [23], and this was followed by a report on major histocompatibility complex class II (MHC-II)-bearing exosomes from B lymphocytes [19] and dendritic cells (DCs) that were capable of stimulating T-cell response $[8,24,25]$. The presence of Rab11 in exosome secretions and the triggering of exosome secretion by calcium transients were established by Savina et al. [26,27], and Rab 27 and Rab35 were identified as regulatory GTPases by Hsu [28]. Baietti demonstrated the presence of apoptosis-linked gene 2-interacting protein X (Alix), vacuolar protein sorting-associated protein 4 (VPS4), and components of the endosomal sorting complexes required for transport (ESCRT) pathway in exosome secretions [29].

\section{Exosome Biogenesis}

The budding of interluminal vesicles from endosomal compartments and their joining together results in the production of multivesicular bodies (MVBs) [30]. Though some MVBs are destined 
for lysosome degradation, some fuse with the plasma membrane to cause the release of exosomes into body fluids (in vivo) or to the culture medium (in vitro) [5,31]. Exosome formation involves the participation of specific proteins, especially ESCRTs, which are involved in the sorting of endosomal proteins for loading into MVBs (Figure 1). Furthermore, interactions between ESCRT-I, -II, and -III with mammalian hepatocyte receptor tyrosine kinase substrate (Hrs) and Vps27 sort ubiquitinated cargos, and trigger their transport into the MVB compartment [30,32]. In vitro experiments revealed that ESCRT-I and -II recruitment drives membrane budding and the recruitment of ESCRT-III via Alix, which binds with the tumor susceptibility gene 101 (TSG101) component of ESCRT-I, while ESCRT-I and -II complexes cause the completion of budding [33]. Dissociation of ESCRT from MVB membranes occurs through the involvement of an ATPase, Vps4 [30,32]. Interestingly, similar patterns of exosome formation were observed in dendritic cells (DCs) [6], antigen-presenting cells (APCs) [19], cytotoxic T-lymphocytes (CTLs) [34], Epstein-Barr virus (EBV)-transformed B-cells [19], mastocytes [35], and platelets [36].

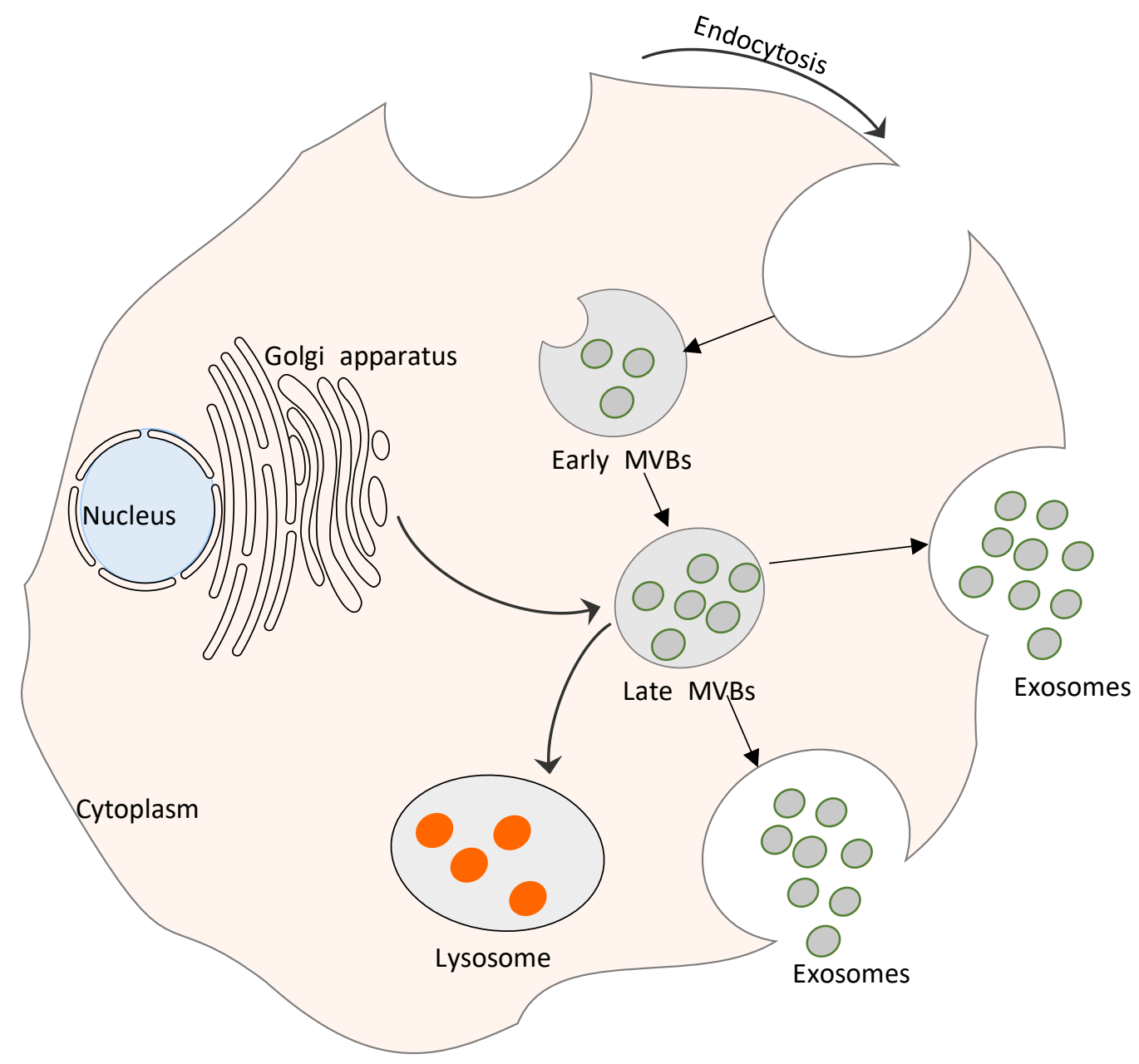

Figure 1. Exosome biogenesis. The process starts with an invagination of the endosomal membrane, and involves Rab GTPase and endosomal sorting complexes required for transport (ESCRTs). The delivery of cargo to recipient cells occurs via ligand-receptor interactions between the exosome and the host cell.

\section{Exosome Composition}

Fluorescence-activated cell sorting (FACS), Western blotting, and mass spectrometry are commonly employed to decipher the exact compositions and to identify the molecular constituents of exosomes $[17,19,37]$. Depending largely on their cellular origins, exosomes contain specific 
sets of protein families of endocytic, cytosolic, and plasma membrane origin. Exosomes are enriched with tetraspanins (cluster of differentiation 9 (CD9), CD26, CD53, CD63, CD81, and CD82), endosome-associated proteins (TSG101, Alix), heat-shock proteins (Hsc70, Hsp90), clathrin, flotillin-1, cytoskeletal elements (ezrin, tubulin, and annexins), Rab proteins, MHC molecules, intercellular adhesion molecule 1 (ICAM-1), co-stimulatory T-cell molecules (CD86), other transmembrane proteins ( $\alpha \mathrm{M}$ (DCs), $\alpha 4 \beta 1$ (reticulocytes)), immunoglobulin A33 (enterocytes), P-selectin (platelets), and matrix metalloproteinases (MMPs) [8] (Figure 2). In addition, lipids, such as ceramides, phosphatidylethanolamine, phosphatidylserine, diacylglyceride, cholesterol, sphingomyelin, and lyso-bisphospatidic acid, were also reported to be present on exosome membranes [38]. Furthermore, exosomes also carry nucleic acid (DNA, messenger RNAs (mRNAs), microRNAs, and other non-coding RNAs) signatures. The levels of different components in exosomes depend largely on the functional states of cells producing them, that is, whether they are stimulated, transformed, rested, or stressed [31].

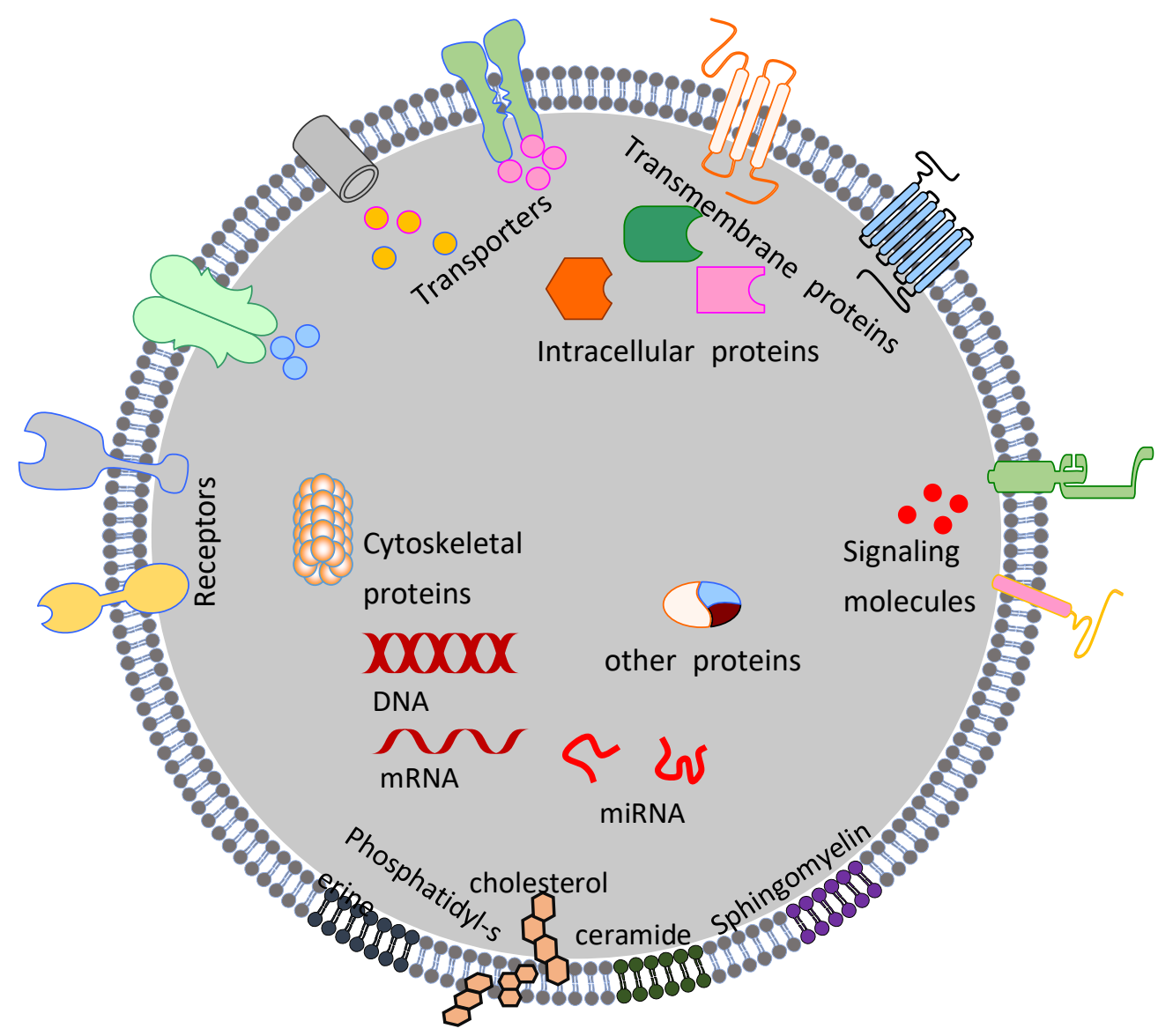

\begin{tabular}{|c|c|c|c|c|c|c|c|c|}
\hline \multicolumn{7}{|c|}{ Proteins } & \multirow[t]{2}{*}{ Lipids } & \multirow[t]{2}{*}{$\begin{array}{c}\text { Nucleic } \\
\text { acids }\end{array}$} \\
\hline Biogenic & Adhesion & $\begin{array}{l}\text { Membrane } \\
\text { transport }\end{array}$ & $\begin{array}{c}\text { Signal } \\
\text { transduction }\end{array}$ & $\begin{array}{c}\text { Antigen } \\
\text { presentation }\end{array}$ & $\begin{array}{c}\text { Heat } \\
\text { shock } \\
\text { proteins }\end{array}$ & Cytoskeleton & & \\
\hline $\begin{array}{l}\text { TSG101, } \\
\text { Alix, } \\
\text { VAMP7, } \\
\text { Rab } \\
\text { proteins }\end{array}$ & $\begin{array}{l}\text { ICAM-1, } \\
\text { Integrins, } \\
\text { Tetraspanins }\end{array}$ & $\begin{array}{l}\text { Annexins, } \\
\text { Dynamin, } \\
\text { Suntaxin }\end{array}$ & $\begin{array}{l}\text { GIPs, Catenin, } \\
\text { Syntenin }\end{array}$ & $\begin{array}{l}\text { MHC-I, } \\
\text { MHC-II, } \\
\text { CD } 86\end{array}$ & $\begin{array}{l}\text { Hsp } 70 \\
\text { Hsc } 90\end{array}$ & $\begin{array}{l}\text { Ezrin, Tubulin, } \\
\text { Moesin }\end{array}$ & $\begin{array}{c}\text { Cholesterol, } \\
\text { Sphingomyelin, } \\
\text { Ceramides, } \\
\text { Phosphatidylcholine }\end{array}$ & $\begin{array}{l}\text { DNA, } \\
\text { RNA, } \\
\text { miRNAs, } \\
\text { ncRNAs }\end{array}$ \\
\hline
\end{tabular}

Figure 2. Structure of an exosome. Exosomes exhibit a complex lipid-bilayer surface structure characterized by an array of surface-localized proteins and membranous lipids, which mediate specific targeting and promote cellular uptake. 


\section{Exosome Secretion}

Exosome secretion into the extracellular milieu modulates gene expression, function, and even cellular differentiation programs. The protein content and genetic material of exosomes can even change the morphology of a recipient cell by interfering with its signaling components. Though little is known of the mechanisms driving MVB to plasma membrane fusion, a study of reticulocytes revealed that exosome secretion is dependent on vesicular-associated molecular pattern 7 (VAMP7) function [39]. Despite the fact that MVB fusion to the plasma membrane requires vesicular soluble $N$-ethylmaleimide-sensitive factor (NSF) attachment protein receptors (v-SNAREs) and target SNAREs (t-SNAREs), the secretion of exosomes with Wingless (Wnt) as a signature depends on arginine (R)-SNARE Ykt6 [40]. The SNARE complex helps with the energy needed for MVB fusion to the plasma membrane, thereby assisting interaction between the two membranes. Independently of its proton-pumping ability, the V0 subunit of v-ATPase, in association with SNAREs, assists fusion by forming fusion pores [41]. Additionally, Rab proteins (Rab11, Rab27b) form a key component of exosome secretion by facilitating the docking of MVBs to the plasma membrane [42]. Exosome secretion is regulated in part by P2X receptor activation on neutrophils and monocytes and by the lipopolysaccharide (LPS)-induced activations of ATP and Toll-like receptor 4 (TLR4) on dendritic cells $[6,42,43]$.

\section{Exosome Function}

Over the past decade, exosomes were implicated in diverse activities in biological systems, possibly by modulating intercellular communication or action at a distance [21,44]. Their immunomodulatory (immunosuppressive or immune-active) effect is one of the different mechanisms caused by regulation of the deliveries of different constituents to recipient cells $[7,45]$. These effects attracted the interest of clinical immunologists [21,46]. Because they produce immunosuppressive molecules, exosomes play dual roles in cancer, that is, they can aid the growth and dissemination of cancer cells by overcoming the activities of T-lymphocytes and natural killer cells (NKCs) and/or modulate the immune system by promoting the differentiation of T-regulatory cells or myeloid cells that elicit anti-tumor responses [47-49]. In particular, exosomes of dendritic cell origin possess MHC-I and -II on their surface, whose binding to T-cell receptors induce an adaptive immune response by activating $\mathrm{CD} 4^{+}$or $\mathrm{CD} 8^{+} \mathrm{T}$ cells [50,51]. However, exosomes from immature DCs reduce adaptive immune responses by inducing apoptosis of the T-cells, thus promoting immunogenic tolerance, as observed in murine models of autoimmune diseases and transplantation [7]. By influencing the balance between pro- and anti-inflammatory effector T-cells, these suppressive exosomes were found to induce the differentiation of T-helper 17 (Th17)/Th1 cells to forkhead box P3 (Foxp3) and Th2 regulatory T cells [52]. Furthermore, Corrado et al. reported on the immune adjuvant potential of exosomes [7]. By acting as antigen-presenting vesicles, exosomes can possibly be exploited to evade graft rejection and treat autoimmune diseases.

Exosomes released by epithelial cells (intestinal epithelial lining) were found to be involved in antigen presentation during inflammatory conditions. It may be that these extracellular vesicles are responsible for providing fixed cells with the ability to act at a distance [53]. In the nervous system, exosomes secreted by cells (neurons, microglia) are utilized in cell communication, and participate in neurite outgrowth formation, neuronal survival, and myelin formation [54]. Moreover, the release of pathogenic proteins (prions, $\beta$-amyloid peptides) by exosomes exacerbates central nervous system disorders [55-57]. In the liver, exosomes participate in a plethora of processes. Epithelial (hepatocytes, cholangiocytes) exosome production was also reported from stellate and adult liver stem cells [58-61]. Despite their effects on extracellular signal-regulated kinase (ERK) signaling and on the expression of microRNA 15a (miR-15a), biliary exosomes were found to inhibit the proliferation of cholangiocytes $[60,62,63]$. Exosomes from mouse hepatocytes contain drug-metabolizing enzymes, such as cytochrome P450 (CYP450) and glutathione S-transferase, which are responsible for the detoxification of toxins and drugs in target cells $[58,64,65]$. 
Exosomes containing oncogenic materials (oncogenic DNA, their transcripts, and activated oncoproteins) are referred to as oncosomes, and they mediate the intercellular transport of these mutant molecules in a systemic manner [66-69]. Fibroblast-derived exosomes promote breast cancer cell dynamics via a Wnt signaling pathway [70]. Analysis of the oncosome cargoes circulating in body fluids appear to offer continuous monitoring of the changing molecular make-ups of different cancers. As such, oncosomes offer promising diagnostic tools for specific cancer subtypes and for determining their prevalence and statuses.

\section{Prospective Applications}

Given their wide-ranging functions, exosomes have huge diagnostic and therapeutic potential. By regulating physiological functions, such as angiogenesis, intercellular communication, coagulation, immune response, and cell survival, exosomes are of immense interest to the scientific fraternity worldwide. Their secretions from cells into body fluids (plasma, urine, cerebrospinal fluid (CSF), saliva, and others) are widely reported (Table 1). Exosomes are mini-copies of cells from which they originate [71] in terms of their antigenicity (cancer and immune cells) and their therapeutic potential (stem and antigen primed-cells); thus, exosomes are viewed as being of immense importance for diagnostic and therapeutic applications. 
Table 1. List of the top exosome proteins. The classification is based on numbers of reported occasions, and includes protein names, symbols, report times, cell origins and species, and methods used for identification. (Reported species: $\mathrm{R}=$ rat, $\mathrm{M}=$ mouse, $\mathrm{H}=$ human, $\mathrm{B}=$ bovine, $\mathrm{D}=$ Drosophila).

\begin{tabular}{|c|c|c|c|c|c|}
\hline No. & Proteins (Species Found) & Symbol & Tissue/Cell/Body Fluids & Identification Methods & References \\
\hline 1. & $\begin{array}{l}\text { Programmed cell death } 6 \\
\text { interacting protein }(\mathrm{R}, \mathrm{M}, \\
\mathrm{H})\end{array}$ & PDCD6IP & $\begin{array}{l}\text { Pancreatic, colorectal, breast, ovarian, } \\
\text { liver, and brain cancer cells, hepatocytes, } \\
\text { neural stem cells, embryonic fibroblast, } \\
\text { dendritic cells, platelets, macrophages, } \\
\text { reticulocytes, urine, serum, saliva }\end{array}$ & $\begin{array}{l}\text { Mass spectrometry, } \\
\text { Western blotting }\end{array}$ & [72-80] \\
\hline 2. & $\begin{array}{c}\text { Heat-shock protein } 8(\mathrm{R}, \\
\mathrm{M}, \mathrm{H}, \mathrm{B})\end{array}$ & HSPA8 & $\begin{array}{l}\text { Prostate, colorectal, and brain cancer } \\
\text { cells, macrophages, mast cells, } \\
\text { adipocytes, reticulocytes, platelets, urine, } \\
\text { milk, serum, saliva }\end{array}$ & $\begin{array}{l}\text { Mass spectrometry, } \\
\text { Western blotting, RNA } \\
\text { sequencing }\end{array}$ & {$[70,77,81-88]$} \\
\hline 3. & Annexin A2 (R, M, H, B) & ANXA2 & $\begin{array}{l}\text { Ovarian, colorectal, and breast cancer } \\
\text { cells, microglia, dendritic cells, } \\
\text { macrophages, fibroblasts, hepatocytes, } \\
\text { adipocytes, reticulocytes, platelets, } \\
\text { thymus, urine, milk, saliva }\end{array}$ & $\begin{array}{l}\text { Mass spectrometry, } \\
\text { Western blotting, RNA } \\
\text { sequencing }\end{array}$ & {$[70,77,80,81,83,84,86,87,89-92]$} \\
\hline 4. & $\begin{array}{l}\text { Syndecan-binding protein } \\
\qquad(\mathrm{R}, \mathrm{M}, \mathrm{H}, \mathrm{B})\end{array}$ & SDCBP & $\begin{array}{c}\text { Pancreatic, ovarian, colorectal, prostate, } \\
\text { and brain cancer cells, dendritic cells, } \\
\text { macrophages, mast cells, reticulocytes, } \\
\text { hepatocytes, platelets, fibroblasts, urine, } \\
\text { milk, saliva }\end{array}$ & $\begin{array}{l}\text { Mass spectrometry, } \\
\text { Western blotting }\end{array}$ & {$[24,77,82-85,87,93]$} \\
\hline 5. & $\begin{array}{c}\text { Heat-shock protein } 90 \\
\text { alpha class A member } 1 \\
(\mathrm{R}, \mathrm{M}, \mathrm{H}, \mathrm{B})\end{array}$ & HSP90AA1 & $\begin{array}{l}\text { Ovarian, colorectal, prostate, and } \\
\text { bladder cancer cells, neural stem cells, } \\
\text { macrophages, mast cells, adipocytes, } \\
\text { reticulocytes, hepatocytes, pancreatic } \\
\text { cells, platelets, fibroblasts, urine, milk, } \\
\text { serum, saliva }\end{array}$ & $\begin{array}{l}\text { Mass spectrometry, } \\
\text { Western blotting, } \\
\text { microarray }\end{array}$ & {$[70,77,80,81,83,84,86,94-98]$} \\
\hline 6. & $\begin{array}{l}\text { Tumor susceptibility gene } \\
101(\mathrm{R}, \mathrm{M}, \mathrm{H}, \mathrm{B}, \mathrm{D})\end{array}$ & TSG101 & $\begin{array}{l}\text { Colorectal, liver, prostate, and bladder } \\
\text { cancer cells, neural stem cells, dendritic } \\
\text { cells, macrophages, reticulocytes, } \\
\text { hepatocytes, platelets, urine, milk, } \\
\text { Drosophila s2 cells. }\end{array}$ & $\begin{array}{l}\text { Mass spectrometry, } \\
\text { Western blotting }\end{array}$ & {$[24,58,76,77,80,83,87,97,99-102]$} \\
\hline 7. & $\begin{array}{c}\text { Eukaryotic translation } \\
\text { elongation factor } 1 \text { alpha } 1 \\
(\mathrm{R}, \mathrm{M}, \mathrm{H}, \mathrm{B})\end{array}$ & EEF1A1 & $\begin{array}{l}\text { Ovarian, colorectal, prostate, and bladder } \\
\text { cancer cells, mast cells, adipocytes, } \\
\text { hepatocytes, reticulocytes, dendritic cells, } \\
\text { platelets, macrophages, pancreatic cells, } \\
\text { fibroblasts, thymus, urine, saliva, milk }\end{array}$ & $\begin{array}{l}\text { Mass spectrometry, RNA } \\
\text { sequencing, microarray }\end{array}$ & $\begin{array}{c}{[24,58,70,77,80,81,83,84,86,87} \\
93,94,103]\end{array}$ \\
\hline
\end{tabular}


Table 1. Cont

\begin{tabular}{|c|c|c|c|c|c|}
\hline No. & Proteins (Species Found) & Symbol & Tissue/Cell/Body Fluids & Identification Methods & References \\
\hline 8. & $\begin{array}{l}\text { Tyrosine-3-monooxygenase/ } \\
\text { tryptophan-5-monooxygenase } \\
\text { activation protein, zeta (R, } \\
\text { M, H, B) }\end{array}$ & YWHAZ & $\begin{array}{l}\text { Ovarian, colorectal, prostate, and } \\
\text { bladder cancer cells, mast cells, } \\
\text { hepatocytes, reticulocytes, dendritic cells, } \\
\text { platelets, pancreatic cells, fibroblasts, } \\
\text { thymus, urine, saliva, milk }\end{array}$ & $\begin{array}{l}\text { Mass spectrometry, } \\
\text { microarray }\end{array}$ & {$[24,70,77,83,84,94,95,104-106]$} \\
\hline 9. & $\begin{array}{c}\text { Eukaryotic translation } \\
\text { elongation factor } 2(\mathrm{R}, \mathrm{M}, \\
\mathrm{H}, \mathrm{B})\end{array}$ & EEF2 & $\begin{array}{l}\text { Ovarian, pancreatic, bladder, colorectal, } \\
\text { prostate, and breast cancer cells, } \\
\text { adipocytes, hepatocytes, reticulocytes, } \\
\text { platelets, thymus, saliva, urine, milk }\end{array}$ & $\begin{array}{l}\text { Mass spectrometry, RNA } \\
\text { sequencing, microarray }\end{array}$ & $\begin{array}{c}{[58,70,77,80,81,83,85-87,93-95} \\
98,103,106-111]\end{array}$ \\
\hline 10. & $\begin{array}{c}\text { Heat-shock protein } 90 \\
\text { alpha class B member } 1(\mathrm{R}, \\
\mathrm{M}, \mathrm{H}, \mathrm{B})\end{array}$ & HSP90AB1 & $\begin{array}{l}\text { Ovarian, pancreatic, bladder, colorectal, } \\
\text { and prostate cancer cells, dendritic cells, } \\
\text { macrophages, mast cells, neural stem, } \\
\text { cells, pancreatic cells, adipocytes, } \\
\text { hepatocytes, reticulocytes, platelets, } \\
\text { thymus, urine, milk, serum }\end{array}$ & $\begin{array}{l}\text { Mass spectrometry, } \\
\text { Western blotting, }\end{array}$ & $\begin{array}{c}{[24,58,77,79-81,83,85,86,88,94-} \\
96,98,103,106,109,111]\end{array}$ \\
\hline 11. & Annexin $5(\mathrm{R}, \mathrm{M}, \mathrm{H})$ & ANXA5 & $\begin{array}{l}\text { Ovarian, bladder, colorectal, and prostate } \\
\text { cancer cells, adipocytes, hepatocytes, } \\
\text { reticulocytes, platelets, thymus, urine, } \\
\text { serum, dendritic cells, fibroblast, } \\
\text { macrophages, mast cells, pancreatic cells, } \\
\text { urine }\end{array}$ & $\begin{array}{l}\text { Mass spectrometry, } \\
\text { Western blotting, } \\
\text { fluorescence-activated cell } \\
\text { sorying }\end{array}$ & $\begin{array}{c}{[24,58,70,73,77,80,81,85,87,88} \\
94,95,103,109-113]\end{array}$ \\
\hline 12. & $\begin{array}{c}\text { Fatty-acid synthase }(\mathrm{R}, \mathrm{M}, \\
\mathrm{H}, \mathrm{B})\end{array}$ & FASN & $\begin{array}{l}\text { Adipocytes, hepatocytes, reticulocytes, } \\
\text { fibroblast, pancreatic cells, milk, breast } \\
\text { milk, bladder, colorectal, ovarian, and } \\
\text { prostrate cancer cells, platelets, serum, } \\
\text { thymus, urine }\end{array}$ & $\begin{array}{l}\text { Mass spectroscopy, } \\
\text { Western blotting, RNA } \\
\text { sequencing }\end{array}$ & $\begin{array}{c}{[58,70,73,77,81,83,85,87,93,95} \\
103,106,109,111,114,115]\end{array}$ \\
\hline 13. & $\begin{array}{l}\text { Tyrosine-3-monooxygenase/ } \\
\text { tryptophan-5-monooxygenase } \\
\text { activation protein, epsilon } \\
\qquad(\mathrm{R}, \mathrm{M}, \mathrm{H}, \mathrm{B})\end{array}$ & YWHAE & $\begin{array}{l}\text { Adipocytes, hepatocytes, reticulocytes, } \\
\text { urine, milk, mast cells, pancreatic cells, } \\
\text { bladder, colorectal, ovarian, and } \\
\text { prostrate cancer cells, platelets, saliva, } \\
\text { thymus, urine }\end{array}$ & Mass spectroscopy & $\begin{array}{c}{[58,73,77,81,83,85,88,94,95,103} \\
106,109-111,113]\end{array}$ \\
\hline 14. & $\begin{array}{l}\text { Clathrin heavy chain }(\mathrm{Hc}) \\
(\mathrm{R}, \mathrm{M}, \mathrm{H})\end{array}$ & CLTC & $\begin{array}{l}\text { Adipocytes, hepatocytes, reticulocytes, } \\
\text { fibroblast, macrophages, bladder, } \\
\text { colorectal, ovarian and prostate cancer } \\
\text { cells, plasma, platelets, saliva, thymus, } \\
\text { urine }\end{array}$ & $\begin{array}{l}\text { Mass Spectroscopy, RNA } \\
\text { Sequencing }\end{array}$ & $\begin{array}{c}{[58,70,73,77,80,81,85,87,103,106} \\
109-111,116,117]\end{array}$ \\
\hline
\end{tabular}




\subsection{Exosomes in Diagnostics}

With specific protein signatures (Alix, TSG101, CD9, CD63, HSP70, and HSP90), RNA (mRNA and miRNA), and characteristic lipid contents, exosomes in body fluids (blood, serum, milk, urine) were investigated as diagnostic markers for the early detection of various diseases $[118,119]$. Exosomal RNAs from saliva, amniotic fluid, and urine were examined in the context of their use as a diagnostic marker for $\mathrm{CD} 24$ polymorphism ( $\mathrm{C} \rightarrow \mathrm{T}$; alanine to valine change) associated with a modulation in the progression of multiple sclerosis (MS), chronic hepatitis B, systemic lupus erythematosus (SLE), and giant-cell arthritis [120].

Increases in the miRNA content released as part of exosomes into body fluids provide insight into the progression of the disease $[118,121]$. Cancer patients exhibit characteristic patterns of RNA and miRNA packaged in circulating MVs, and a major proportion of these are exosomes [122]. Diseases like diabetes, lung cancer, and colorectal cancer have definite miRNA expression patterns [123-126]. MicroRNA 92a is downregulated in plasma in hepatocellular carcinoma and leukemia $[127,128]$. Furthermore, serum miRNAs (miR25, miR223) were reported to provide specific miRNA signatures in non-small-cell lung cancer and liposarcoma $[129,130]$. Serum miR-141 levels were used to differentiate prostate cancer patients and normal controls [131,132].

Human saliva, which is another indispensable source of exosomes, contains nucleic acids and proteins, and provides diagnostic signatures for different diseases [133]. Levels of miRNAs in saliva samples obtained from parotid and submandibular/sublingual regions from healthy controls and patients suffering from Sjogren's syndrome showed that miRNAs highly expressed in parotid glands were differentially expressed. Michael et al. (2010) reported a marked difference between the six highly expressed miRNAs in Sjogren's syndrome and healthy controls (Sjogren's syndrome: hsa-miR-23a, hsa-miR-27b, hsa-miR-29b, hsa-miR-29c, hsa-miR-150, hsa-miR-335; and healthy controls: hsa-let-7c, hsa-miR-17, hsa-miR-128, hsa-miR-150, hsa-miR-212, hsa-miR-1908) [134].

Urine also serves as an efficient source of exosomal markers of urogenital diseases. Proteomic analysis of urine helped identify eight proteins useful for the detection of bladder cancer [135]. Exosomes from urine possess mRNA-encoding protein prostate cancer-associated 3 (PCA3) and the transmembrane protease serine 2 (TMPRSS2)-erythroblast transformation-specific (ETS)-related gene (ERG) fusion product, an entity over-expressed in prostate cancer [136]. The detection of proteins, mRNAs, and miRNAs in patient serum, saliva, and/or urine offers a unique means of diagnosing and detecting early disease. Exosomes provide more cost-effective, accurate, and non-invasive diagnostic tools than traditional invasive methods, and potentially better outcomes [137]. By acting as antigen-presenting vesicles, exosomes derived from malignant effusions, neoplastic cells, or tumor-pulsed dendritic cells are currently being explored for use as non-invasive biomarkers in the diagnosis of cancer, in addition to their use as a prognostic marker in cardiovascular and neurodegenerative disorders (Alzheimer's and Parkinson's) and for the management of infectious diseases (diphtheria, tuberculosis), autoimmune diseases (lupus erythromatosus and rheumatoid arthritis). Accordingly, pharmaceutical companies, such as Exosomics and Exosome Diagnostics, are focusing on the commercialization of exosome-based diagnostics.

\subsection{Exosomes in Therapeutics}

The properties of exosomes, which include bioavailability, distribution, and stability under in vivo and in vitro conditions, and their abilities to cross the blood-brain barrier (BBB) and regulate gene expression via the transfer of miRNA and small interfering RNA (siRNA) to target cells means they are preferred over other EVs as potential therapeutics [137]. Furthermore, because exosomes encapsulate and, thus, protect contents from degradation, their use in disease immunotherapy is viewed with considerable optimism. The successful completion of two independent phase I trials of dexosomes (autologous DC-derived exosomes) for treating non-small-cell lung (NSCL) cancer confirmed their potential therapeutic applications [15,24,138,139]. Because they topically present MHC-I, MHC-II, and $\mathrm{CD1}$, dexosomes induce innate and adaptive immune responses. More specifically, they activate 
cytotoxic T-cells, induce tumor rejection in mice, and promote NKC activation and NKC-dependent anti-tumor effects in immunocompetent mice [140]. Furthermore, dexosome immunotherapy is considered safe [141].

Mesenchymal stem cells (MSCs) are stromal cells with well-known therapeutic potentials. These cells are present in bone marrow, umbilical cord, and adipose tissue [142]. The exosomes derived from MSCs added a new paradigm of therapeutic applications in regenerative medicine. MSC-Ex therapies are preferred over MSC transplantation because they induce fewer immune responses, increase safety, and reduce storage, shipment, and administration concerns. Thus, "off-the-shelf" products with negligible immunogenicity are readily developed using exosomes. By using MSC exosomes rather than MSCs, limitations regarding replicating cell transplantation and safety concerns are much alleviated. The administration of MSC-derived MVs intravenously was found to accelerate recovery after glycerol-induced acute renal injury in SCID mice [143], which argues well for the use of MSC-Ex as an adjuvant therapy for acute renal injury. Yan et al. (2017) reported the use of human umbilical cord MSC-derived exosomes (hucMSC-Ex) for the treatment of liver disease, and assessed their efficacy and their action mechanism [144]. On measuring antioxidant activities and assessing the hepato-protective effect of hucMSC-Ex in vitro and in vivo, these workers found that hucMSC-Ex (at a systemic dose of $16 \mathrm{mg} / \mathrm{kg}$ ) reduced reactive oxygen species (ROS) and malondialdehyde (MDA) levels and, thus, increased the viabilities of $\mathrm{L} 02$ cells exposed to $\mathrm{CCl}_{4}$ or $\mathrm{H}_{2} \mathrm{O}_{2}$ and effectively rescued recipient mice from $\mathrm{CCl}_{4}$-induced liver failure. The mechanism of rescue by hucMSC-Ex-derived cells was attributed to glutathione peroxidase 1 (GPX1), which detoxifies $\mathrm{CCl}_{4}$ and $\mathrm{H}_{2} \mathrm{O}_{2}$, thereby reducing oxidative stress and apoptosis. It was also shown that a knockdown of GPX1 in hucMSCs abolished the antioxidant and anti-apoptotic abilities of hucMSC-Ex, and reduced the hepato-protective effects of hucMSC-Ex in vitro and in vivo.

By aiding the adhesion of hematopoietic stem-cell progenitor cells to endothelia, microvesicles derived from platelets (PMVs) supported the engraftment of transplanted stem cells in lethally irradiated mice [145]. Beltrami et al. (2017) observed enrichment of miRNAs of potential cardiovascular origin in the exosomes of pericardial fluid [146]. Pericardial fluid (PF) is an ultrafiltrate of plasma found in the pericardium. On the mechanistic level, they demonstrated the proangiogenic role of miRNA let-7b-5p along with its inhibitory effect on TGFBR1 in ECs, following delivery of functional let-7b-5p via PF exosomes. Downregulation of let-7b-5p miRNA in PF exosomes impaired the angiogenic response by ECs. At a functional level, the authors reported that PF exosomes enhanced survival, proliferation, and networking of cultured endothelial cells (ECs), and restored the pro-angiogenic function of ECs depleted of their endogenous miRNA content.

Cardiosphere-derived cells (CDCs) induce the therapeutic regeneration of the infarcted human heart by stimulating angiogenesis and causing functional improvements of infarcted myocardium. Interestingly, CDCs reduced scar sizes and the growth of new functional myocardium, which was previously considered an irreparable form of injury [147]. Ibrahim et al. (2014) showed CDC exosomes enhanced angiogenesis and promoted cardiomyocyte survival and proliferation [148]. The authors demonstrated the effects of CDC exosomes on angiogenesis, cardiomyocyte proliferation, and apoptosis using human umbilical cord endothelial cells (HUVECs), and found CDC exosomes stimulated angiogenesis, improved cardiac function, and increased viable mass after myocardial infarction (MI) in an established preclinical model versus normal human dermal fibroblast (NHDF) exosomes. A comparative study of CDC- and NHDF-derived exosomes showed CDC exosomes promoted tube formation by HUVECs, which is indicative of enhanced angiogenesis. The authors compared the miRNA repertoires of CDC and NHDF exosomes using a PCR array and showed that CDC exosomes are rich in miR-146a, which is a main mediator of the beneficial effects of these exosomes against MI. In addition, they showed inhibition of exosome secretion using GW4869 (a reversible inhibitor of neutral sphingomyelinase), which prevents exosome release and attenuates CDC benefits by inhibiting exosome secretion. 
Exosomes are known to have neuroprotective effects, that is, they aid neuron healing and the regeneration of peripheral nerves, and also act as mediators of neurodegenerative diseases. Furthermore, their ability to cross the blood-brain barrier makes them indispensable neurotherapeutic carriers of drugs and therapeutics. In the nervous system, exosome-mediated neuronal communication facilitates cell-to-cell interactions. The transfer of miRNAs and protein entities from glial cells to neural exons was reported a few years ago [149]. Sulfatides, galactocerebrosides, and cholesterol are myelin lipids primarily found in myelin sheaths and they are required for nerve conduction; they showed their release into the exosomes via oligodendrocytes [150]. The involvement of MVBs in Alzheimer's patients was first suspected when it was observed that more MVBs were present in forebrain cortical neurons, and in Huntington's disease, mutated huntingtin protein was found to accumulate in MVBs.

\section{Conclusions}

Exosomes are importantly involved in intercellular communication and in the pathogeneses of various human diseases. Because exosomes are readily accessible in body fluids, their genetic profiles provide new diagnostic and prognostic tools and open new therapeutic possibilities. Their abilities to carry mRNAs, miRNAs, and non-coding RNAs provide an efficient means of controlling protein expressions at a distance in different target cells. The use of exosomes as delivery vehicles offers significant advantages over existing delivery systems due to their small size, non-toxic natures, and target specificities [151]. Interest in exosomes by scientists and physicians increased markedly, but we are still in an early stage of deciphering the molecular mechanisms involved in exosome biogenesis and cargo recruitment.

As our understanding of the biology of exosomes increases, so will our knowledge of design principles and exosomal conjugates. DC-derived exosomes engineered to express rabies virus glycoprotein showed positive results in the delivery of siRNA across the BBB in murine models [152]. To facilitate the release of therapeutic cargoes under specific conditions, bioengineered liposomes and polymer nano-carriers based on exosome templates are needed to achieve better targeting and increase drug uptakes $[153,154]$. The use of lipid-protein compositions that increase exosome fusion to recipient cells and the engineering of liposomes for exosomic proteins like tetraspanins hold great promise for the targeted delivering of drugs to tumor tissues [155-157]. Although exosomes provide a new platform for therapy and biomarker development, many challenges remain to be overcome, but continued progress in this field is sure to reveal the secrets responsible for their physiological and pathological roles.

Funding: Author Arif Tasleem Jan would like to thank the University Grants Commission (UGC) for start-up grant (F.30-441/2018 BSR). The research was supported by the National Research Foundation of Korea (NRF) funded by the Korean government (MSIP: Grant No. NRF-2018R1A2B6001020) and the Creative Economy Leading Technology Development Program through the Gyeongsanbuk-Do and Gyeongbuk Science and the Technology Promotion Center of Korea (SF316001A).

Acknowledgments: The authors dedicate this paper to Mudasir Ahmad Malik, who left for heavenly abode during the preparation of this manuscript.

Conflicts of Interest: The authors declare no conflict of interest.

\section{References}

1. Johnstone, R.M.; Adam, M.; Hammond, J.R.; Orr, L.; Turbide, C. Vesicle formation during reticulocyte maturation. Association of plasma membrane activities with released vesicles (exosomes). J. Biol. Chem. 1987, 262, 9412-9420. [PubMed]

2. Harding, C.; Heuser, J.; Stahl, P. Receptor-mediated endocytosis of transferrin and recycling of the transferrin receptor in rat reticulocytes. J. Cell Biol. 1983, 97, 329-339. [CrossRef] [PubMed]

3. Bobrie, A.; Colombo, M.; Raposo, G.; Thery, C. Exosome secretion: Molecular mechanisms and roles in immune responses. Traffic 2011, 12, 1659-1668. [CrossRef] 
4. Mathivanan, S.; Ji, H.; Simpson, R.J. Exosomes: Extracellular organelles important in intercellular communication. J. Proteom. 2010, 73, 1907-1920. [CrossRef]

5. Vlassov, A.V.; Magdaleno, S.; Setterquist, R.; Conrad, R. Exosomes: Current knowledge of their composition, biological functions, and diagnostic and therapeutic potentials. Biochim. Biophys. Acta 2012, 1820, 940-948. [CrossRef] [PubMed]

6. Thery, C.; Ostrowski, M.; Segura, E. Membrane vesicles as conveyors of immune responses. Nat. Rev. Immunol. 2009, 9, 581-593. [CrossRef]

7. Corrado, C.; Raimondo, S.; Chiesi, A.; Ciccia, F.; De Leo, G.; Alessandro, R. Exosomes as intercellular signaling organelles involved in health and disease: Basic science and clinical applications. Int. J. Mol. Sci. 2013, 14, 5338-5366. [CrossRef]

8. Thery, C.; Zitvogel, L.; Amigorena, S. Exosomes: Composition, biogenesis and function. Nat. Rev. Immunol. 2002, 2, 569-579. [CrossRef]

9. Naseri, Z.; Oskuee, R.K.; Jaafari, M.R.; Forouzandeh Moghadam, M. Exosome-mediated delivery of functionally active mirna-142-3p inhibitor reduces tumorigenicity of breast cancer in vitro and in vivo. Int. J. Nanomed. 2018, 13, 7727-7747. [CrossRef]

10. Fitzgerald, W.; Freeman, M.L.; Lederman, M.M.; Vasilieva, E.; Romero, R.; Margolis, L. A system of cytokines encapsulated in extracellular vesicles. Sci. Rep. 2018, 8, 8973. [CrossRef]

11. Charoenviriyakul, C.; Takahashi, Y.; Morishita, M.; Nishikawa, M.; Takakura, Y. Role of extracellular vesicle surface proteins in the pharmacokinetics of extracellular vesicles. Mol. Pharm. 2018, 15, 1073-1080. [CrossRef] [PubMed]

12. Jesus, S.; Soares, E.; Cruz, M.T.; Borges, O. Exosomes as adjuvants for the recombinant hepatitis b antigen: First report. Eur. J. Pharm. Biopharm. 2018, 133, 1-11. [CrossRef] [PubMed]

13. Messenger, S.W.; Woo, S.S.; Sun, Z.; Martin, T.F.J. A ca(2+)-stimulated exosome release pathway in cancer cells is regulated by munc13-4. J. Cell Biol. 2018, 217, 2877-2890. [CrossRef] [PubMed]

14. Akers, J.C.; Gonda, D.; Kim, R.; Carter, B.S.; Chen, C.C. Biogenesis of extracellular vesicles (ev): Exosomes, microvesicles, retrovirus-like vesicles, and apoptotic bodies. J. Neurooncol. 2013, 113, 1-11. [CrossRef]

15. Lamparski, H.G.; Metha-Damani, A.; Yao, J.Y.; Patel, S.; Hsu, D.H.; Ruegg, C.; Le Pecq, J.B. Production and characterization of clinical grade exosomes derived from dendritic cells. J. Immunol. Methods 2002, 270, 211-226. [CrossRef]

16. Koga, K.; Matsumoto, K.; Akiyoshi, T.; Kubo, M.; Yamanaka, N.; Tasaki, A.; Nakashima, H.; Nakamura, M.; Kuroki, S.; Tanaka, M.; et al. Purification, characterization and biological significance of tumor-derived exosomes. Anticancer Res. 2005, 25, 3703-3707.

17. Clayton, A.; Court, J.; Navabi, H.; Adams, M.; Mason, M.D.; Hobot, J.A.; Newman, G.R.; Jasani, B. Analysis of antigen presenting cell derived exosomes, based on immuno-magnetic isolation and flow cytometry. $J$. Immunol. Methods 2001, 247, 163-174. [CrossRef]

18. Dragovic, R.A.; Gardiner, C.; Brooks, A.S.; Tannetta, D.S.; Ferguson, D.J.P.; Hole, P.; Carr, B.; Redman, C.W.G.; Harris, A.L.; Dobson, P.J.; et al. Sizing and phenotyping of cellular vesicles using nanoparticle tracking analysis. Nanomed. Nanotechnol. Biol. Med. 2011, 7, 780-788. [CrossRef]

19. Raposo, G.; Nijman, H.W.; Stoorvogel, W.; Liejendekker, R.; Harding, C.V.; Melief, C.J.; Geuze, H.J. B lymphocytes secrete antigen-presenting vesicles. J. Exp. Med. 1996, 183, 1161-1172. [CrossRef]

20. Diaz-Varela, M.; de Menezes-Neto, A.; Perez-Zsolt, D.; Gamez-Valero, A.; Segui-Barber, J.; Izquierdo-Useros, N.; Martinez-Picado, J.; Fernandez-Becerra, C.; Del Portillo, H.A. Proteomics study of human cord blood reticulocyte-derived exosomes. Sci. Rep. 2018, 8, 14046. [CrossRef]

21. Raposo, G.; Stoorvogel, W. Extracellular vesicles: Exosomes, microvesicles, and friends. J. Cell Biol. 2013, 200, 373-383. [CrossRef] [PubMed]

22. Pan, B.T.; Johnstone, R.M. Fate of the transferrin receptor during maturation of sheep reticulocytes in vitro: Selective externalization of the receptor. Cell 1983, 33, 967-978. [CrossRef]

23. Vidal, M.J.; Stahl, P.D. The small gtp-binding proteins rab4 and arf are associated with released exosomes during reticulocyte maturation. Eur. J. Cell Biol. 1993, 60, 261-267.

24. Thery, C.; Boussac, M.; Veron, P.; Ricciardi-Castagnoli, P.; Raposo, G.; Garin, J.; Amigorena, S. Proteomic analysis of dendritic cell-derived exosomes: A secreted subcellular compartment distinct from apoptotic vesicles. J. Immunol. 2001, 166, 7309-7318. [CrossRef] [PubMed] 
25. Zitvogel, L.; Regnault, A.; Lozier, A.; Wolfers, J.; Flament, C.; Tenza, D.; Ricciardi-Castagnoli, P.; Raposo, G.; Amigorena, S. Eradication of established murine tumors using a novel cell-free vaccine: Dendritic cell-derived exosomes. Nat. Med. 1998, 4, 594-600. [CrossRef] [PubMed]

26. Savina, A.; Fader, C.M.; Damiani, M.T.; Colombo, M.I. Rab11 promotes docking and fusion of multivesicular bodies in a calcium-dependent manner. Traffic 2005, 6, 131-143. [CrossRef]

27. Savina, A.; Vidal, M.; Colombo, M.I. The exosome pathway in k562 cells is regulated by rab11. J. Cell Sci. 2002, 115, 2505-2515.

28. Hsu, C.; Morohashi, Y.; Yoshimura, S.; Manrique-Hoyos, N.; Jung, S.; Lauterbach, M.A.; Bakhti, M.; Gronborg, M.; Mobius, W.; Rhee, J.; et al. Regulation of exosome secretion by rab35 and its gtpase-activating proteins tbc1d10a-c. J. Cell Biol. 2010, 189, 223-232. [CrossRef]

29. Baietti, M.F.; Zhang, Z.; Mortier, E.; Melchior, A.; Degeest, G.; Geeraerts, A.; Ivarsson, Y.; Depoortere, F.; Coomans, C.; Vermeiren, E.; et al. Syndecan-syntenin-alix regulates the biogenesis of exosomes. Nat. Cell Biol. 2012, 14, 677-685. [CrossRef]

30. Hosseini, H.M.; Fooladi, A.A.; Nourani, M.R.; Ghanezadeh, F. The role of exosomes in infectious diseases. Inflamm. Allergy Drug Targets 2013, 12, 29-37. [CrossRef]

31. Bang, C.; Thum, T. Exosomes: New players in cell-cell communication. Int. J. Biochem. Cell Biol. 2012, 44, 2060-2064. [CrossRef] [PubMed]

32. Babst, M.; Katzmann, D.J.; Estepa-Sabal, E.J.; Meerloo, T.; Emr, S.D. Escrt-iii: An endosome-associated heterooligomeric protein complex required for mvb sorting. Dev. Cell 2002, 3, 271-282. [CrossRef]

33. McCullough, J.; Fisher, R.D.; Whitby, F.G.; Sundquist, W.I.; Hill, C.P. Alix-chmp4 interactions in the human escrt pathway. Proc. Natl. Acad. Sci. USA 2008, 105, 7687-7691. [CrossRef] [PubMed]

34. Peters, P.J.; Geuze, H.J.; Van der Donk, H.A.; Slot, J.W.; Griffith, J.M.; Stam, N.J.; Clevers, H.C.; Borst, J. Molecules relevant for $\mathrm{t}$ cell-target cell interaction are present in cytolytic granules of human $\mathrm{t}$ lymphocytes. Eur. J. Immunol. 1989, 19, 1469-1475. [CrossRef]

35. Raposo, G.; Tenza, D.; Mecheri, S.; Peronet, R.; Bonnerot, C.; Desaymard, C. Accumulation of major histocompatibility complex class ii molecules in mast cell secretory granules and their release upon degranulation. Mol. Biol. Cell 1997, 8, 2631-2645. [CrossRef] [PubMed]

36. Heijnen, H.F.; Schiel, A.E.; Fijnheer, R.; Geuze, H.J.; Sixma, J.J. Activated platelets release two types of membrane vesicles: Microvesicles by surface shedding and exosomes derived from exocytosis of multivesicular bodies and alpha-granules. Blood 1999, 94, 3791-3799. [PubMed]

37. Cosme, J.; Liu, P.P.; Gramolini, A.O. The cardiovascular exosome: Current perspectives and potential. Proteom. 2013, 13, 1654-1659. [CrossRef]

38. Schorey, J.S.; Bhatnagar, S. Exosome function: From tumor immunology to pathogen biology. Traffic 2008, 9 , 871-881. [CrossRef]

39. Fader, C.M.; Sanchez, D.G.; Mestre, M.B.; Colombo, M.I. Ti-vamp/vamp7 and vamp3/cellubrevin: Two v-snare proteins involved in specific steps of the autophagy/multivesicular body pathways. Biochim. Biophys. Acta 2009, 1793, 1901-1916. [CrossRef]

40. Gross, J.C.; Chaudhary, V.; Bartscherer, K.; Boutros, M. Active wnt proteins are secreted on exosomes. Nat. Cell Biol. 2012, 14, 1036-1045. [CrossRef]

41. Marshansky, V.; Futai, M. The v-type h+-atpase in vesicular trafficking: Targeting, regulation and function. Curr. Opin. Cell Biol. 2008, 20, 415-426. [CrossRef] [PubMed]

42. Hu, G.; Gong, A.Y.; Roth, A.L.; Huang, B.Q.; Ward, H.D.; Zhu, G.; Larusso, N.F.; Hanson, N.D.; Chen, X.M. Release of luminal exosomes contributes to tlr4-mediated epithelial antimicrobial defense. PLoS Pathog. 2013, 9, e1003261. [CrossRef] [PubMed]

43. Bhatnagar, S.; Schorey, J.S. Exosomes released from infected macrophages contain mycobacterium avium glycopeptidolipids and are proinflammatory. J. Biol. Chem. 2007, 282, 25779-25789. [CrossRef] [PubMed]

44. Zhang, C.; Ji, Q.; Yang, Y.; Li, Q.; Wang, Z. Exosome: Function and role in cancer metastasis and drug resistance. Technol. Cancer Res. Treat. 2018, 17, 1533033818763450. [CrossRef] [PubMed]

45. Azimi, M.; Ghabaee, M.; Moghadasi, A.N.; Noorbakhsh, F.; Izad, M. Immunomodulatory function of treg-derived exosomes is impaired in patients with relapsing-remitting multiple sclerosis. Immunol. Res. 2018, 66, 513-520. [CrossRef] [PubMed]

46. Kahlert, C.; Kalluri, R. Exosomes in tumor microenvironment influence cancer progression and metastasis. J. Mol. Med. 2013, 91, 431-437. [CrossRef] [PubMed] 
47. Zhang, H.G.; Grizzle, W.E. Exosomes and cancer: A newly described pathway of immune suppression. Clin. Cancer Res. 2011, 17, 959-964. [CrossRef] [PubMed]

48. Sun, W.; Luo, J.D.; Jiang, H.; Duan, D.D. Tumor exosomes: A double-edged sword in cancer therapy. Acta Pharmacol. Sin. 2018, 39, 534-541. [CrossRef] [PubMed]

49. Gomari, H.; Forouzandeh Moghadam, M.; Soleimani, M. Targeted cancer therapy using engineered exosome as a natural drug delivery vehicle. Onco Targets Ther. 2018, 11, 5753-5762. [CrossRef] [PubMed]

50. Muntasell, A.; Berger, A.C.; Roche, P.A. T cell-induced secretion of mhc class ii-peptide complexes on b cell exosomes. EMBO J. 2007, 26, 4263-4272. [CrossRef] [PubMed]

51. Wahlund, C.J.E.; Gucluler, G.; Hiltbrunner, S.; Veerman, R.E.; Naslund, T.I.; Gabrielsson, S. Exosomes from antigen-pulsed dendritic cells induce stronger antigen-specific immune responses than microvesicles in vivo. Sci. Rep. 2017, 7, 17095. [CrossRef]

52. Yin, W.; Ouyang, S.; Li, Y.; Xiao, B.; Yang, H. Immature dendritic cell-derived exosomes: A promise subcellular vaccine for autoimmunity. Inflammation 2013, 36, 232-240. [CrossRef]

53. Van Niel, G.; Raposo, G.; Candalh, C.; Boussac, M.; Hershberg, R.; Cerf-Bensussan, N.; Heyman, M. Intestinal epithelial cells secrete exosome-like vesicles. Gastroenterology 2001, 121, 337-349. [CrossRef] [PubMed]

54. Lachenal, G.; Pernet-Gallay, K.; Chivet, M.; Hemming, F.J.; Belly, A.; Bodon, G.; Blot, B.; Haase, G.; Goldberg, Y.; Sadoul, R. Release of exosomes from differentiated neurons and its regulation by synaptic glutamatergic activity. Mol. Cell Neurosci. 2011, 46, 409-418. [CrossRef]

55. Fevrier, B.; Vilette, D.; Archer, F.; Loew, D.; Faigle, W.; Vidal, M.; Laude, H.; Raposo, G. Cells release prions in association with exosomes. Proc. Natl. Acad. Sci. USA 2004, 101, 9683-9688. [CrossRef] [PubMed]

56. Rajendran, L.; Honsho, M.; Zahn, T.R.; Keller, P.; Geiger, K.D.; Verkade, P.; Simons, K. Alzheimer's disease beta-amyloid peptides are released in association with exosomes. Proc. Natl. Acad. Sci. USA 2006, 103, 11172-11177. [CrossRef] [PubMed]

57. Abdulrahman, B.A.; Abdelaziz, D.H.; Schatzl, H.M. Autophagy regulates exosomal release of prions in neuronal cells. J. Biol. Chem. 2018, 293, 8956-8968. [CrossRef] [PubMed]

58. Conde-Vancells, J.; Rodriguez-Suarez, E.; Embade, N.; Gil, D.; Matthiesen, R.; Valle, M.; Elortza, F.; Lu, S.C.; Mato, J.M.; Falcon-Perez, J.M. Characterization and comprehensive proteome profiling of exosomes secreted by hepatocytes. J. Proteome Res. 2008, 7, 5157-5166. [CrossRef]

59. Fonsato, V.; Collino, F.; Herrera, M.B.; Cavallari, C.; Deregibus, M.C.; Cisterna, B.; Bruno, S.; Romagnoli, R.; Salizzoni, M.; Tetta, C.; et al. Human liver stem cell-derived microvesicles inhibit hepatoma growth in scid mice by delivering antitumor micrornas. Stem Cells 2012, 30, 1985-1998. [CrossRef] [PubMed]

60. Masyuk, A.I.; Huang, B.Q.; Ward, C.J.; Gradilone, S.A.; Banales, J.M.; Masyuk, T.V.; Radtke, B.; Splinter, P.L.; LaRusso, N.F. Biliary exosomes influence cholangiocyte regulatory mechanisms and proliferation through interaction with primary cilia. Am. J. Physiol. Gastrointest. Liver Physiol. 2010, 299, G990-G999. [CrossRef]

61. Deng, F.; Magee, N.; Zhang, Y. Decoding the role of extracellular vesicles in liver diseases. Liver Res. 2017, 1, 147-155. [CrossRef] [PubMed]

62. Sato, K.; Meng, F.; Venter, J.; Giang, T.; Glaser, S.; Alpini, G. Author correction: The role of the secretin/secretin receptor axis in inflammatory cholangiocyte communication via extracellular vesicles. Sci. Rep. 2018, 8, 11238. [CrossRef] [PubMed]

63. Sato, K.; Meng, F.; Venter, J.; Giang, T.; Glaser, S.; Alpini, G. The role of the secretin/secretin receptor axis in inflammatory cholangiocyte communication via extracellular vesicles. Sci. Rep. 2017, 7, 11183. [CrossRef] [PubMed]

64. Kumar, S.; Sinha, N.; Gerth, K.A.; Rahman, M.A.; Yallapu, M.M.; Midde, N.M. Specific packaging and circulation of cytochromes p450, especially 2e1 isozyme, in human plasma exosomes and their implications in cellular communications. Biochem. Biophys. Res. Commun. 2017, 491, 675-680. [CrossRef]

65. Yang, S.J.; Wang, D.D.; Li, J.; Xu, H.Z.; Shen, H.Y.; Chen, X.; Zhou, S.Y.; Zhong, S.L.; Zhao, J.H.; Tang, J.H. Predictive role of gstp1-containing exosomes in chemotherapy-resistant breast cancer. Gene 2017, 623, 5-14. [CrossRef]

66. Holmgren, L. Horizontal gene transfer: You are what you eat. Biochem. Biophys. Res. Commun. 2010, 396, 147-151. [CrossRef] [PubMed]

67. Garnier, D.; Magnus, N.; Lee, T.H.; Bentley, V.; Meehan, B.; Milsom, C.; Montermini, L.; Kislinger, T.; Rak, J. Cancer cells induced to express mesenchymal phenotype release exosome-like extracellular vesicles carrying tissue factor. J. Biol. Chem. 2012, 287, 43565-43572. [CrossRef] 
68. Al-Nedawi, K.; Meehan, B.; Micallef, J.; Lhotak, V.; May, L.; Guha, A.; Rak, J. Intercellular transfer of the oncogenic receptor egfrviii by microvesicles derived from tumour cells. Nat. Cell Biol. 2008, 10, 619-624. [CrossRef] [PubMed]

69. Luhtala, N.; Aslanian, A.; Yates, J.R., 3rd; Hunter, T. Secreted glioblastoma nanovesicles contain intracellular signaling proteins and active ras incorporated in a farnesylation-dependent manner. J. Biol. Chem. 2017, 292, 611-628. [CrossRef] [PubMed]

70. Luga, V.; Zhang, L.; Viloria-Petit, A.M.; Ogunjimi, A.A.; Inanlou, M.R.; Chiu, E.; Buchanan, M.; Hosein, A.N.; Basik, M.; Wrana, J.L. Exosomes mediate stromal mobilization of autocrine wnt-pcp signaling in breast cancer cell migration. Cell 2012, 151, 1542-1556. [CrossRef]

71. Johnstone, R.M. The jeanne manery-fisher memorial lecture 1991. Maturation of reticulocytes: Formation of exosomes as a mechanism for shedding membrane proteins. Biochem. Cell Biol. 1992, 70, 179-190. [CrossRef] [PubMed]

72. Park, J.E.; Tan, H.S.; Datta, A.; Lai, R.C.; Zhang, H.; Meng, W.; Lim, S.K.; Sze, S.K. Hypoxic tumor cell modulates its microenvironment to enhance angiogenic and metastatic potential by secretion of proteins and exosomes. Mol. Cell Proteom. 2010, 9, 1085-1099. [CrossRef]

73. Kharaziha, P.; Chioureas, D.; Rutishauser, D.; Baltatzis, G.; Lennartsson, L.; Fonseca, P.; Azimi, A.; Hultenby, K.; Zubarev, R.; Ullen, A.; et al. Molecular profiling of prostate cancer derived exosomes may reveal a predictive signature for response to docetaxel. Oncotarget 2015, 6, 21740-21754. [CrossRef]

74. Phuyal, S.; Skotland, T.; Hessvik, N.P.; Simolin, H.; Overbye, A.; Brech, A.; Parton, R.G.; Ekroos, K.; Sandvig, K.; Llorente, A. The ether lipid precursor hexadecylglycerol stimulates the release and changes the composition of exosomes derived from pc-3 cells. J. Biol. Chem. 2015, 290, 4225-4237. [CrossRef]

75. Peinado, H.; Aleckovic, M.; Lavotshkin, S.; Matei, I.; Costa-Silva, B.; Moreno-Bueno, G.; Hergueta-Redondo, M.; Williams, C.; Garcia-Santos, G.; Ghajar, C.; et al. Melanoma exosomes educate bone marrow progenitor cells toward a pro-metastatic phenotype through met. Nat. Med. 2012, 18, 883-891. [CrossRef] [PubMed]

76. Faure, J.; Lachenal, G.; Court, M.; Hirrlinger, J.; Chatellard-Causse, C.; Blot, B.; Grange, J.; Schoehn, G.; Goldberg, Y.; Boyer, V.; et al. Exosomes are released by cultured cortical neurones. Mol. Cell Neurosci. 2006, 31, 642-648. [CrossRef] [PubMed]

77. Carayon, K.; Chaoui, K.; Ronzier, E.; Lazar, I.; Bertrand-Michel, J.; Roques, V.; Balor, S.; Terce, F.; Lopez, A.; Salome, L.; et al. Proteolipidic composition of exosomes changes during reticulocyte maturation. J. Biol. Chem. 2011, 286, 34426-34439. [CrossRef]

78. Trajkovic, K.; Hsu, C.; Chiantia, S.; Rajendran, L.; Wenzel, D.; Wieland, F.; Schwille, P.; Brugger, B.; Simons, M. Ceramide triggers budding of exosome vesicles into multivesicular endosomes. Science 2008, 319, 1244-1247. [CrossRef]

79. Cossetti, C.; Iraci, N.; Mercer, T.R.; Leonardi, T.; Alpi, E.; Drago, D.; Alfaro-Cervello, C.; Saini, H.K.; Davis, M.P.; Schaeffer, J.; et al. Extracellular vesicles from neural stem cells transfer ifn-gamma via ifngr1 to activate stat1 signaling in target cells. Mol. Cell 2014, 56, 193-204. [CrossRef]

80. Hassani, K.; Olivier, M. Immunomodulatory impact of leishmania-induced macrophage exosomes: A comparative proteomic and functional analysis. PLoS Negl. Trop. Dis. 2013, 7, e2185. [CrossRef]

81. Lee, J.E.; Moon, P.G.; Lee, I.K.; Baek, M.C. Proteomic analysis of extracellular vesicles released by adipocytes of otsuka long-evans tokushima fatty (oletf) rats. Protein J. 2015, 34, 220-235. [CrossRef]

82. Graner, M.W.; Alzate, O.; Dechkovskaia, A.M.; Keene, J.D.; Sampson, J.H.; Mitchell, D.A.; Bigner, D.D. Proteomic and immunologic analyses of brain tumor exosomes. FASEB J. 2009, 23, 1541-1557. [CrossRef]

83. Reinhardt, T.A.; Sacco, R.E.; Nonnecke, B.J.; Lippolis, J.D. Bovine milk proteome: Quantitative changes in normal milk exosomes, milk fat globule membranes and whey proteomes resulting from staphylococcus aureus mastitis. J. Proteom. 2013, 82, 141-154. [CrossRef] [PubMed]

84. Buschow, S.I.; van Balkom, B.W.; Aalberts, M.; Heck, A.J.; Wauben, M.; Stoorvogel, W. Mhc class ii-associated proteins in b-cell exosomes and potential functional implications for exosome biogenesis. Immunol. Cell Biol. 2010, 88, 851-856. [CrossRef] [PubMed]

85. Choi, D.S.; Lee, J.M.; Park, G.W.; Lim, H.W.; Bang, J.Y.; Kim, Y.K.; Kwon, K.H.; Kwon, H.J.; Kim, K.P.; Gho, Y.S. Proteomic analysis of microvesicles derived from human colorectal cancer cells. J. Proteome Res. 2007, 6, 4646-4655. [CrossRef] 
86. Xu, R.; Greening, D.W.; Rai, A.; Ji, H.; Simpson, R.J. Highly-purified exosomes and shed microvesicles isolated from the human colon cancer cell line lim1863 by sequential centrifugal ultrafiltration are biochemically and functionally distinct. Methods 2015, 87, 11-25. [CrossRef] [PubMed]

87. He, M.; Qin, H.; Poon, T.C.; Sze, S.C.; Ding, X.; Co, N.N.; Ngai, S.M.; Chan, T.F.; Wong, N. Hepatocellular carcinoma-derived exosomes promote motility of immortalized hepatocyte through transfer of oncogenic proteins and rnas. Carcinogenesis 2015, 36, 1008-1018. [CrossRef] [PubMed]

88. Pisitkun, T.; Shen, R.F.; Knepper, M.A. Identification and proteomic profiling of exosomes in human urine. Proc. Natl. Acad. Sci. USA 2004, 101, 13368-13373. [CrossRef] [PubMed]

89. Potolicchio, I.; Carven, G.J.; Xu, X.; Stipp, C.; Riese, R.J.; Stern, L.J.; Santambrogio, L. Proteomic analysis of microglia-derived exosomes: Metabolic role of the aminopeptidase cd13 in neuropeptide catabolism. J. Immunol. 2005, 175, 2237-2243. [CrossRef]

90. Stamer, W.D.; Hoffman, E.A.; Luther, J.M.; Hachey, D.L.; Schey, K.L. Protein profile of exosomes from trabecular meshwork cells. J. Proteom. 2011, 74, 796-804. [CrossRef] [PubMed]

91. Staubach, S.; Razawi, H.; Hanisch, F.G. Proteomics of muc1-containing lipid rafts from plasma membranes and exosomes of human breast carcinoma cells mcf-7. Proteomics 2009, 9, 2820-2835. [CrossRef] [PubMed]

92. Chavez-Munoz, C.; Kilani, R.T.; Ghahary, A. Profile of exosomes related proteins released by differentiated and undifferentiated human keratinocytes. J. Cell Physiol. 2009, 221, 221-231. [CrossRef] [PubMed]

93. Admyre, C.; Johansson, S.M.; Qazi, K.R.; Filen, J.J.; Lahesmaa, R.; Norman, M.; Neve, E.P.; Scheynius, A.; Gabrielsson, S. Exosomes with immune modulatory features are present in human breast milk. J. Immunol. 2007, 179, 1969-1978. [CrossRef]

94. Valadi, H.; Ekstrom, K.; Bossios, A.; Sjostrand, M.; Lee, J.J.; Lotvall, J.O. Exosome-mediated transfer of mrnas and micrornas is a novel mechanism of genetic exchange between cells. Nat. Cell Biol. 2007, 9, 654-659. [CrossRef] [PubMed]

95. Lee, H.S.; Jeong, J.; Lee, K.J. Characterization of vesicles secreted from insulinoma nit-1 cells. J. Proteome Res. 2009, 8, 2851-2862. [CrossRef]

96. Ochieng, J.; Pratap, S.; Khatua, A.K.; Sakwe, A.M. Anchorage-independent growth of breast carcinoma cells is mediated by serum exosomes. Exp. Cell Res. 2009, 315, 1875-1888. [CrossRef] [PubMed]

97. Demory Beckler, M.; Higginbotham, J.N.; Franklin, J.L.; Ham, A.J.; Halvey, P.J.; Imasuen, I.E.; Whitwell, C.; Li, M.; Liebler, D.C.; Coffey, R.J. Proteomic analysis of exosomes from mutant kras colon cancer cells identifies intercellular transfer of mutant kras. Mol. Cell Proteom. 2013, 12, 343-355. [CrossRef] [PubMed]

98. Hosseini-Beheshti, E.; Pham, S.; Adomat, H.; Li, N.; Tomlinson Guns, E.S. Exosomes as biomarker enriched microvesicles: Characterization of exosomal proteins derived from a panel of prostate cell lines with distinct ar phenotypes. Mol. Cell Proteom. 2012, 11, 863-885. [CrossRef]

99. Beckett, K.; Monier, S.; Palmer, L.; Alexandre, C.; Green, H.; Bonneil, E.; Raposo, G.; Thibault, P.; Le Borgne, R.; Vincent, J.P. Drosophila s2 cells secrete wingless on exosome-like vesicles but the wingless gradient forms independently of exosomes. Traffic 2013, 14, 82-96. [CrossRef]

100. Mittelbrunn, M.; Gutierrez-Vazquez, C.; Villarroya-Beltri, C.; Gonzalez, S.; Sanchez-Cabo, F.; Gonzalez, M.A.; Bernad, A.; Sanchez-Madrid, F. Unidirectional transfer of microrna-loaded exosomes from $t$ cells to antigen-presenting cells. Nat. Commun. 2011, 2, 282. [CrossRef]

101. Lim, J.W.; Mathias, R.A.; Kapp, E.A.; Layton, M.J.; Faux, M.C.; Burgess, A.W.; Ji, H.; Simpson, R.J. Restoration of full-length apc protein in sw480 colon cancer cells induces exosome-mediated secretion of dkk-4. Electrophoresis 2012, 33, 1873-1880. [CrossRef]

102. Ohshima, K.; Inoue, K.; Fujiwara, A.; Hatakeyama, K.; Kanto, K.; Watanabe, Y.; Muramatsu, K.; Fukuda, Y.; Ogura, S.; Yamaguchi, K.; et al. Let-7 microrna family is selectively secreted into the extracellular environment via exosomes in a metastatic gastric cancer cell line. PLoS ONE 2010, 5, e13247. [CrossRef] [PubMed]

103. Welton, J.L.; Khanna, S.; Giles, P.J.; Brennan, P.; Brewis, I.A.; Staffurth, J.; Mason, M.D.; Clayton, A. Proteomics analysis of bladder cancer exosomes. Mol. Cell Proteom. 2010, 9, 1324-1338. [CrossRef]

104. Ji, H.; Erfani, N.; Tauro, B.J.; Kapp, E.A.; Zhu, H.J.; Moritz, R.L.; Lim, J.W.; Simpson, R.J. Difference gel electrophoresis analysis of ras-transformed fibroblast cell-derived exosomes. Electrophoresis 2008, 29, 2660-2671. [CrossRef]

105. Lazar, I.; Clement, E.; Ducoux-Petit, M.; Denat, L.; Soldan, V.; Dauvillier, S.; Balor, S.; Burlet-Schiltz, O.; Larue, L.; Muller, C.; et al. Proteome characterization of melanoma exosomes reveals a specific signature for metastatic cell lines. Pigment Cell Melanoma Res. 2015, 28, 464-475. [CrossRef] [PubMed] 
106. Liang, B.; Peng, P.; Chen, S.; Li, L.; Zhang, M.; Cao, D.; Yang, J.; Li, H.; Gui, T.; Li, X.; et al. Characterization and proteomic analysis of ovarian cancer-derived exosomes. J. Proteom. 2013, 80, 171-182. [CrossRef] [PubMed]

107. Nazarenko, I.; Rana, S.; Baumann, A.; McAlear, J.; Hellwig, A.; Trendelenburg, M.; Lochnit, G.; Preissner, K.T.; Zoller, M. Cell surface tetraspanin tspan8 contributes to molecular pathways of exosome-induced endothelial cell activation. Cancer Res. 2010, 70, 1668-1678. [CrossRef]

108. Van Balkom, B.W.; Eisele, A.S.; Pegtel, D.M.; Bervoets, S.; Verhaar, M.C. Quantitative and qualitative analysis of small rnas in human endothelial cells and exosomes provides insights into localized rna processing, degradation and sorting. J. Extracell. Vesicles 2015, 4, 26760. [CrossRef]

109. Pienimaeki-Roemer, A.; Kuhlmann, K.; Bottcher, A.; Konovalova, T.; Black, A.; Orso, E.; Liebisch, G.; Ahrens, M.; Eisenacher, M.; Meyer, H.E.; et al. Lipidomic and proteomic characterization of platelet extracellular vesicle subfractions from senescent platelets. Transfusion 2015, 55, 507-521. [CrossRef] [PubMed]

110. Gonzalez-Begne, M.; Lu, B.; Han, X.; Hagen, F.K.; Hand, A.R.; Melvin, J.E.; Yates, J.R. Proteomic analysis of human parotid gland exosomes by multidimensional protein identification technology (mudpit). J. Proteome Res. 2009, 8, 1304-1314. [CrossRef]

111. Skogberg, G.; Gudmundsdottir, J.; van der Post, S.; Sandstrom, K.; Bruhn, S.; Benson, M.; Mincheva-Nilsson, L.; Baranov, V.; Telemo, E.; Ekwall, O. Characterization of human thymic exosomes. PLoS ONE 2013, 8, e67554. [CrossRef] [PubMed]

112. Keller, S.; Konig, A.K.; Marme, F.; Runz, S.; Wolterink, S.; Koensgen, D.; Mustea, A.; Sehouli, J.; Altevogt, P. Systemic presence and tumor-growth promoting effect of ovarian carcinoma released exosomes. Cancer Lett. 2009, 278, 73-81. [CrossRef] [PubMed]

113. Conde-Vancells, J.; Rodriguez-Suarez, E.; Gonzalez, E.; Berisa, A.; Gil, D.; Embade, N.; Valle, M.; Luka, Z.; Elortza, F.; Wagner, C.; et al. Candidate biomarkers in exosome-like vesicles purified from rat and mouse urine samples. Proteom. Clin. Appl. 2010, 4, 416-425. [CrossRef]

114. Zhao, X.; Wu, Y.; Duan, J.; Ma, Y.; Shen, Z.; Wei, L.; Cui, X.; Zhang, J.; Xie, Y.; Liu, J. Quantitative proteomic analysis of exosome protein content changes induced by hepatitis b virus in huh-7 cells using silac labeling and lc-ms/ms. J. Proteome Res. 2014, 13, 5391-5402. [CrossRef] [PubMed]

115. Raj, D.A.; Fiume, I.; Capasso, G.; Pocsfalvi, G. A multiplex quantitative proteomics strategy for protein biomarker studies in urinary exosomes. Kidney Int. 2012, 81, 1263-1272. [CrossRef]

116. Looze, C.; Yui, D.; Leung, L.; Ingham, M.; Kaler, M.; Yao, X.; Wu, W.W.; Shen, R.F.; Daniels, M.P.; Levine, S.J. Proteomic profiling of human plasma exosomes identifies ppargamma as an exosome-associated protein. Biochem. Biophys. Res. Commun. 2009, 378, 433-438. [CrossRef]

117. Gonzales, P.A.; Pisitkun, T.; Hoffert, J.D.; Tchapyjnikov, D.; Star, R.A.; Kleta, R.; Wang, N.S.; Knepper, M.A. Large-scale proteomics and phosphoproteomics of urinary exosomes. J. Am. Soc. Nephrol. 2009, 20, 363-379. [CrossRef]

118. Ratajczak, J.; Miekus, K.; Kucia, M.; Zhang, J.; Reca, R.; Dvorak, P.; Ratajczak, M.Z. Embryonic stem cell-derived microvesicles reprogram hematopoietic progenitors: Evidence for horizontal transfer of mrna and protein delivery. Leukemia 2006, 20, 847-856. [CrossRef]

119. Kim, Y.S.; Ahn, J.S.; Kim, S.; Kim, H.J.; Kim, S.H.; Kang, J.S. The potential theragnostic (diagnostic+therapeutic) application of exosomes in diverse biomedical fields. Korean J. Physiol. Pharmacol. 2018, 22, 113-125. [CrossRef]

120. Keller, S.; Rupp, C.; Stoeck, A.; Runz, S.; Fogel, M.; Lugert, S.; Hager, H.D.; Abdel-Bakky, M.S.; Gutwein, P.; Altevogt, P. Cd24 is a marker of exosomes secreted into urine and amniotic fluid. Kidney Int. 2007, 72, 1095-1102. [CrossRef]

121. Kim, H.K.; Song, K.S.; Park, Y.S.; Kang, Y.H.; Lee, Y.J.; Lee, K.R.; Ryu, K.W.; Bae, J.M.; Kim, S. Elevated levels of circulating platelet microparticles, vegf, il-6 and rantes in patients with gastric cancer: Possible role of a metastasis predictor. Eur. J. Cancer 2003, 39, 184-191. [CrossRef]

122. Lasser, C.; Alikhani, V.S.; Ekstrom, K.; Eldh, M.; Paredes, P.T.; Bossios, A.; Sjostrand, M.; Gabrielsson, S.; Lotvall, J.; Valadi, H. Human saliva, plasma and breast milk exosomes contain rna: Uptake by macrophages. J. Transl. Med. 2011, 9, 9. [CrossRef]

123. Chen, X.; Ba, Y.; Ma, L.; Cai, X.; Yin, Y.; Wang, K.; Guo, J.; Zhang, Y.; Chen, J.; Guo, X.; et al. Characterization of micrornas in serum: A novel class of biomarkers for diagnosis of cancer and other diseases. Cell Res. 2008, 18, 997-1006. [CrossRef] [PubMed] 
124. Mao, L.; Li, X.; Gong, S.; Yuan, H.; Jiang, Y.; Huang, W.; Sun, X.; Dang, X. Serum exosomes contain ecrg4 mrna that suppresses tumor growth via inhibition of genes involved in inflammation, cell proliferation, and angiogenesis. Cancer Gene Ther. 2018, 25, 248-259. [CrossRef] [PubMed]

125. Sanz-Rubio, D.; Martin-Burriel, I.; Gil, A.; Cubero, P.; Forner, M.; Khalyfa, A.; Marin, J.M. Stability of circulating exosomal mirnas in healthy subjects. Sci. Rep. 2018, 8, 10306. [CrossRef]

126. Zhang, S.; Zhang, X.; Fu, X.; Li, W.; Xing, S.; Yang, Y. Identification of common differentially-expressed mirnas in ovarian cancer cells and their exosomes compared with normal ovarian surface epithelial cell cells. Oncol. Lett. 2018, 16, 2391-2401. [CrossRef]

127. Leblanc, P.; Alais, S.; Porto-Carreiro, I.; Lehmann, S.; Grassi, J.; Raposo, G.; Darlix, J.L. Retrovirus infection strongly enhances scrapie infectivity release in cell culture. EMBO J. 2006, 25, 2674-2685. [CrossRef] [PubMed]

128. Fu, F.; Jiang, W.; Zhou, L.; Chen, Z. Circulating exosomal mir-17-5p and mir-92a-3p predict pathologic stage and grade of colorectal cancer. Transl. Oncol. 2018, 11, 221-232. [CrossRef]

129. Poon, K.S.; Palanisamy, K.; Chang, S.S.; Sun, K.T.; Chen, K.B.; Li, P.C.; Lin, T.C.; Li, C.Y. Plasma exosomal mir-223 expression regulates inflammatory responses during cardiac surgery with cardiopulmonary bypass. Sci. Rep. 2017, 7, 10807. [CrossRef]

130. Casadei, L.; Calore, F.; Creighton, C.J.; Guescini, M.; Batte, K.; Iwenofu, O.H.; Zewdu, A.; Braggio, D.A.; Bill, K.L.; Fadda, P.; et al. Exosome-derived mir-25-3p and mir-92a-3p stimulate liposarcoma progression. Cancer Res. 2017, 77, 3846-3856. [CrossRef]

131. Mitchell, P.S.; Parkin, R.K.; Kroh, E.M.; Fritz, B.R.; Wyman, S.K.; Pogosova-Agadjanyan, E.L.; Peterson, A.; Noteboom, J.; O’Briant, K.C.; Allen, A.; et al. Circulating micrornas as stable blood-based markers for cancer detection. Proc. Natl. Acad. Sci. USA 2008, 105, 10513-10518. [CrossRef]

132. Li, Z.; Ma, Y.Y.; Wang, J.; Zeng, X.F.; Li, R.; Kang, W.; Hao, X.K. Exosomal microrna-141 is upregulated in the serum of prostate cancer patients. Onco Targets Ther. 2016, 9, 139-148. [PubMed]

133. Palanisamy, V.; Sharma, S.; Deshpande, A.; Zhou, H.; Gimzewski, J.; Wong, D.T. Nanostructural and transcriptomic analyses of human saliva derived exosomes. PLoS ONE 2010, 5, e8577. [CrossRef] [PubMed]

134. Michael, A.; Bajracharya, S.D.; Yuen, P.S.; Zhou, H.; Star, R.A.; Illei, G.G.; Alevizos, I. Exosomes from human saliva as a source of microrna biomarkers. Oral. Dis. 2010, 16, 34-38. [CrossRef]

135. Li, C.Y.; Li, H.J.; Zhang, T.; Gao, H.S.; Chang, J.W.; Men, X.L.; Wu, J.; Li, J.M. Significance of apolipoprotein a1 as biomarker for early diagnosis and classification of bladder urothelial carcinoma. Zhonghua Lao Dong Wei Sheng Zhi Ye Bing Za Zhi 2013, 31, 266-270. [PubMed]

136. Nilsson, J.; Skog, J.; Nordstrand, A.; Baranov, V.; Mincheva-Nilsson, L.; Breakefield, X.O.; Widmark, A. Prostate cancer-derived urine exosomes: A novel approach to biomarkers for prostate cancer. Br. J. Cancer 2009, 100, 1603-1607. [CrossRef] [PubMed]

137. De Toro, J.; Herschlik, L.; Waldner, C.; Mongini, C. Emerging roles of exosomes in normal and pathological conditions: New insights for diagnosis and therapeutic applications. Front. Immunol. 2015, 6, 203. [CrossRef] [PubMed]

138. Escudier, B.; Dorval, T.; Chaput, N.; André, F.; Caby, M.-P.; Novault, S.; Flament, C.; Leboulaire, C.; Borg, C.; Amigorena, S.; et al. Vaccination of metastatic melanoma patients with autologous dendritic cell (dc) derived-exosomes: Results of thefirst phase i clinical trial. J. Transl. Med. 2005, 3, 10. [CrossRef] [PubMed]

139. Morse, M.A.; Garst, J.; Osada, T.; Khan, S.; Hobeika, A.; Clay, T.M.; Valente, N.; Shreeniwas, R.; Sutton, M.A.; Delcayre, A.; et al. A phase i study of dexosome immunotherapy in patients with advanced non-small cell lung cancer. J. Transl. Med. 2005, 3, 9. [CrossRef] [PubMed]

140. Chaput, N.; Flament, C.; Viaud, S.; Taieb, J.; Roux, S.; Spatz, A.; Andre, F.; LePecq, J.B.; Boussac, M.; Garin, J.; et al. Dendritic cell derived-exosomes: Biology and clinical implementations. J. Leukoc Biol. 2006, 80, 471-478. [CrossRef]

141. Viaud, S.; Thery, C.; Ploix, S.; Tursz, T.; Lapierre, V.; Lantz, O.; Zitvogel, L.; Chaput, N. Dendritic cell-derived exosomes for cancer immunotherapy: What's next? Cancer Res. 2010, 70, 1281-1285. [CrossRef]

142. Lee, R.H.; Kim, B.; Choi, I.; Kim, H.; Choi, H.S.; Suh, K.; Bae, Y.C.; Jung, J.S. Characterization and expression analysis of mesenchymal stem cells from human bone marrow and adipose tissue. Cell Physiol. Biochem. 2004, 14, 311-324. [CrossRef] [PubMed] 
143. Bruno, S.; Grange, C.; Deregibus, M.C.; Calogero, R.A.; Saviozzi, S.; Collino, F.; Morando, L.; Busca, A.; Falda, M.; Bussolati, B.; et al. Mesenchymal stem cell-derived microvesicles protect against acute tubular injury. J. Am. Soc. Nephrol. 2009, 20, 1053-1067. [CrossRef]

144. Yan, Y.; Jiang, W.; Tan, Y.; Zou, S.; Zhang, H.; Mao, F.; Gong, A.; Qian, H.; Xu, W. Hucmsc exosome-derived gpx1 is required for the recovery of hepatic oxidant injury. Mol. Ther. 2017, 25, 465-479. [CrossRef] [PubMed]

145. Janowska-Wieczorek, A.; Majka, M.; Kijowski, J.; Baj-Krzyworzeka, M.; Reca, R.; Turner, A.R.; Ratajczak, J.; Emerson, S.G.; Kowalska, M.A.; Ratajczak, M.Z. Platelet-derived microparticles bind to hematopoietic stem/progenitor cells and enhance their engraftment. Blood 2001, 98, 3143-3149. [CrossRef] [PubMed]

146. Beltrami, C.; Besnier, M.; Shantikumar, S.; Shearn, A.I.; Rajakaruna, C.; Laftah, A.; Sessa, F.; Spinetti, G.; Petretto, E.; Angelini, G.D.; et al. Human pericardial fluid contains exosomes enriched with cardiovascular-expressed micrornas and promotes therapeutic angiogenesis. Mol. Ther. 2017, 25, 679-693. [CrossRef] [PubMed]

147. Makkar, R.R.; Smith, R.R.; Cheng, K.; Malliaras, K.; Thomson, L.E.; Berman, D.; Czer, L.S.; Marban, L.; Mendizabal, A.; Johnston, P.V.; et al. Intracoronary cardiosphere-derived cells for heart regeneration after myocardial infarction (caduceus): A prospective, randomised phase 1 trial. Lancet 2012, 379, 895-904. [CrossRef]

148. Ibrahim, A.G.; Cheng, K.; Marban, E. Exosomes as critical agents of cardiac regeneration triggered by cell therapy. Stem Cell Rep. 2014, 2, 606-619. [CrossRef]

149. Skog, J.; Wurdinger, T.; van Rijn, S.; Meijer, D.H.; Gainche, L.; Sena-Esteves, M.; Curry, W.T., Jr.; Carter, B.S.; Krichevsky, A.M.; Breakefield, X.O. Glioblastoma microvesicles transport rna and proteins that promote tumour growth and provide diagnostic biomarkers. Nat. Cell Biol. 2008, 10, 1470-1476. [CrossRef]

150. Fruhbeis, C.; Frohlich, D.; Kramer-Albers, E.M. Emerging roles of exosomes in neuron-glia communication. Front. Physiol. 2012, 3, 119. [CrossRef]

151. Marcus, M.E.; Leonard, J.N. Fedexosomes: Engineering therapeutic biological nanoparticles that truly deliver. Pharmaceuticals 2013, 6, 659-680. [CrossRef] [PubMed]

152. Alvarez-Erviti, L.; Seow, Y.; Yin, H.; Betts, C.; Lakhal, S.; Wood, M.J. Delivery of sirna to the mouse brain by systemic injection of targeted exosomes. Nat. Biotechnol. 2011, 29, 341-345. [CrossRef] [PubMed]

153. Kooijmans, S.A.; Aleza, C.G.; Roffler, S.R.; van Solinge, W.W.; Vader, P.; Schiffelers, R.M. Display of gpi-anchored anti-egfr nanobodies on extracellular vesicles promotes tumour cell targeting. J. Extracell. Vesicles 2016, 5, 31053. [CrossRef] [PubMed]

154. Kooijmans, S.A.; Stremersch, S.; Braeckmans, K.; de Smedt, S.C.; Hendrix, A.; Wood, M.J.; Schiffelers, R.M.; Raemdonck, K.; Vader, P. Electroporation-induced sirna precipitation obscures the efficiency of sirna loading into extracellular vesicles. J. Control Release 2013, 172, 229-238. [CrossRef] [PubMed]

155. Rana, S.; Yue, S.; Stadel, D.; Zoller, M. Toward tailored exosomes: The exosomal tetraspanin web contributes to target cell selection. Int. J. Biochem. Cell Biol. 2012, 44, 1574-1584. [CrossRef]

156. El-Andaloussi, S.; Lee, Y.; Lakhal-Littleton, S.; Li, J.; Seow, Y.; Gardiner, C.; Alvarez-Erviti, L.; Sargent, I.L.; Wood, M.J. Exosome-mediated delivery of sirna in vitro and in vivo. Nat. Protoc. 2012, 7, 2112-2126. [CrossRef] [PubMed]

157. Subra, C.; Laulagnier, K.; Perret, B.; Record, M. Exosome lipidomics unravels lipid sorting at the level of multivesicular bodies. Biochimie 2007, 89, 205-212. [CrossRef]

(c) 2019 by the authors. Licensee MDPI, Basel, Switzerland. This article is an open access article distributed under the terms and conditions of the Creative Commons Attribution (CC BY) license (http://creativecommons.org/licenses/by/4.0/). 